(C) John Miers, 2015. The definitive, peer reviewed and edited version of this article is published in Studies in Comics, 6,1,pp. 145-156, 2015 https://doi.org/10.1386/stic.6.1.145 1 


\section{Depiction and demarcation in comics: Towards an account of the medium as a drawing}

practice

John Miers, University of the Arts London

\section{Abstract}

Despite the insistence of many authors on the primacy of the visual in comics, there has been comparatively little attention given to the drawing practices that create comics texts. This article will argue for the value of, and make some initial proposals regarding the nature of, an account of comics production as a distinct drawing practice, not as a rejection of language-centred accounts, but as a necessary complement to the understandings they enable. Accounts of depiction by Kendall Walton, Michael Podro and Patrick Maynard describe a process of imagining into drawn marks, in which the viewer maintains an awareness of their own cognitive activity in taking the sight of the image before them as the sight of the depicted subject. Readerly awareness of this type is wellknown to comics researchers through discussion of the cognitive effort involved in achieving what Scott McCloud famously describes as 'closure', yet such discussions generally begin with the assumption of the reader's recognition of depicted scenes. A full account of this fundamental operation of comics reading also requires an account of the methods by which readers use what is perceptually presented to them to imagine events taking place within the images. Walton's theory of 'mimesis as make-believe' will be used here to suggest the way in which fictional truths are generated by drawing styles common to comics. Drawing on the phenomenological grounding of Walton's approach, I will argue for its compatibility with conceptual metaphor theory, and that the less obviously pictorial drawing conventions of emanata operate as visual metaphors that emerge both from our embodied experience of the world.

\section{Keywords}


drawing

depiction

metaphor

embodied cognition

Kendall Walton

Ernst Gombrich

\section{Introduction}

Kendall Walton's (1990) theory of 'mimesis as make-believe' classifies the distinction between depiction and description in terms of a self-conscious use of one's own perceptual activity as an object of imagination, rather than a referential relationship between signs and objects, thereby redrawing the lines on which this distinction is made in semiotically inclined methodologies. Many semioticians have explicitly questioned the validity of the notion of the iconic sign, and the approach outlined here may be seen as compatible with Jonathan Culler's assertion that 'Study of the way in which a drawing of a horse represents a horse is perhaps more properly the concern of a philosophical theory of representation than of a linguistically based semiology' (2002: 19). The ability of traditional semiotic classifications to adequately analyse the ways in which comics function has frequently been questioned in comics studies, and the aim of this article is to introduce the philosophical theory of representation developed by Walton, focusing on the examination of a few common features of drawing in comics through the lens of his definition of depiction.

Before introducing Walton's theory, I'll highlight two issues discussed in the work of Ernst Gombrich to which he responds, elaborating one and providing an alternative explanation for the other. We will indeed begin with representations of horses, but not pictures: children's hobby horses are the starting point. 
The theory of 'make-believe' has its origins in what Walton (2008: 64) describes as a famous but little-used lecture of Gombrich's, Meditations on a Hobby Horse (1963). In this lecture, Gombrich speculates on the idea that the psychological processes at the heart of our understanding of all visual art may be the same as those by which a child, for the purposes of play, imaginatively transforms a simple stick into a hobby horse which can be 'ridden' (1963). This idea is given fuller realization in what Patrick Maynard (2005) describes as Gombrich's 'same mill principle', developed in his classic Art and Illusion (2002), which states that our perception of visual representations draws on the same cognitive processes by which we organize our perception of the world. In Meditations on a Hobby Horse (1963), the key concept for Gombrich is that of function: the child is able to imagine the stick as a horse not because of any resemblance, but because it can be 'ridden'. Gombrich rejects both a resemblance notion of representation and a referential one, positioning the hobby horse instead as a 'substitute' for the real horse it represents to its rider. Walton elaborates on this basic idea to rephrase it in terms of the creation of fictions: the child creates a fictional world in which it is fictionally true that he rides a horse. This is the basis of the make-believe theory of representation: works of art function as props in games of make-believe, which mandate particular imaginative activities on the part of the viewer.

\section{Walton's theory of depiction}

The issue in Gombrich which Walton contradicts relates to our ability to attend to both the material surface of a depiction and the objects it depicts simultaneously. For Gombrich, this is an impossibility. Proceeding from the observation that we cannot observe both the duck and the rabbit in the famous illusion simultaneously, Gombrich invokes Kenneth Clark's description of attempting to observe the moment in the viewing of a Velazquez painting when 'the brush strokes and dabs of pigment on the canvas transformed themselves into a vision of transfigured reality as he stepped back. But try as he might, stepping backward and forward, he could never hold both visions at the same time' (2002: 5). 
Walton resolves this apparent contradiction through his focus on the viewer of a depiction's selfconscious imaginings about their own perceptual activities. He introduces his definition of depiction as follows:

The viewer of Meindert Hobbema's Wooded Landscape with a Water Mill plays a game in which it is fictional that he sees a red-roofed mill. As a participant in the game, he imagines that this is so. And this self-imagining is done in a first-person manner: he imagines seeing a mill, not just that he sees one, and he imagines this from the inside. Moreover, his actual act of looking at the painting is what makes it fictional that he looks at a mill. And this act is such that fictionally it itself is his looking at a mill; he imagines of his looking that its object is a mill. We might sum this up by saying that in seeing the canvas he imaginatively sees a mill. Let's say provisionally that to be a 'depiction' is to have the function of serving as a prop in visual games of this sort. (1990: 293, original emphasis)

All of which sounds suspiciously close to some sort of copy theory of representation. But the point is not that the viewer of the Hobbema imagines or believes that they are actually looking at a mill: we do not, as a rule, take the depiction to be the thing depicted. Instead, in looking at a picture, we generate fictional truths about our own act of looking: we make it fictional, within the game of make-believe we are playing with the depiction, that our act of looking at the picture is the act of looking at the thing it depicts. And this extends to senses other than the visual: in the child's game of make-believe, it is also fictional that the sensation of the wooden hobby horse between his legs is the sensation of the horse's flanks; if the child rhythmically taps the end of the stick on the ground as he moves around, it is fictional of his hearing of that sound that it is the hearing of the horse's hooves as it trots or gallops. 


\section{Richness and vivacity}

The use of our perception as a means of generating fictional truths about a work results in what Walton describes as games of relative richness and vivacity. Different styles of depiction offer varied ways in which we are able to employ our seeing in this manner. The viewer of a painting by Vermeer is able to observe a detailed play of light that reveals the form of depicted objects, whereas the reader of Jeff Smith's Bone (2004) ascertains the form and position of objects by the outlines from which they are constructed. In page 1238 (Figure 1), panel 6, it is fictional that the underside of Smiley Bone's left foot will be less strongly lit than its tip, because light is most commonly cast from above and there is nothing in this scene to suggest that things should be otherwise. But the shadows are not depicted. Our examination of the fur of the rat creature to whom he is serving quiche will reach its limits sooner than will our examination of the texture of the materials in the foreground of Vermeer's Girl Reading a Letter by an Open Window. The rendering style of Bone (2004), one more characteristic of comics than that of Vermeer, creates images that, as props, mandate imaginative games that are attenuated to some degree. But are these games any less rich and vivid?

Figure 1: Smith (2004: 1238).

It might be better to say that a drawing style such as Smith's is better suited to the use we usually make of the props with which comics present us, specifically their status as elements in a drawn narrative (how Walton's theory of make-believe is extended when the pictures being discussed form a narrative is beyond the scope of this article, but Grennan (2011) provides a detailed discussion of how Walton's self-conscious imagining is extended in narrative drawing). Comparing Vermeer's painting with Matisse's The Red Studio, Walton highlights the difference in what types of fictional truths are directly generated in each work. In the Matisse painting, fictional truths about threedimensional objects are generated directly by the outlines present on the canvas, and fictional truths 
about the play of light and shadow are implied by the presence of a window at the left-hand side of the painting. This is reversed to a degree in Vermeer: fictional truths about spatial relations between objects are generated by examining the detail of the way light falls across the room (Walton 1990: 319-24).

We might say that the manner of directly generating fictional truths about spatial relationships between objects adopted in Bone (2004) or The Red Studio is more appropriate for comics, because generally we want to have direct access to fictional truths about how bodies are moving in space, or facial expressions changing, from panel to panel, and do not want to have to generate them from more directly generated truths about the play of light and shadow. This assertion could be seen as a reframing of the common assertion that 'too much detail' disrupts the flow of reading - it's not because the relative visual richness of very detailed styles forces us to linger more, it's that we have to expend extra effort and make inferences rather than directly using our perception to ascertain the relevant fictional truths about the content of a given panel.

\section{Narrative properties of linework}

The fact that drawn lines allow us as viewers to imagine the intentional movement that created the trace described by Maynard adds a second layer of depictive richness to images so constructed. Michael Podro argues that representation is doubled when a figure in motion is represented with lines: 'the line relates itself to the figure twice over, once by its shape and once by its apparent impulse' (1998: 9). Patrick Maynard echoes this in defining drawing as an 'action [that] leaves, as a trace of its path, a mark of some kind, and is done for that purpose' (2005: 62).

The jaunty forward thrust of Smiley Bone's foot is accentuated by the fluidity of the curved and tapering line that describes it through the viewer's imaginative reconstruction of the impulse that created that line. It is only in drawing that shape and movement can be connected - 'projected onto each other' (Podro 1998: 9) in this way. And it can go both ways - the gesture - the 'impulse' - of 
the line can communicate the figure's 'motility', but equally the depicted motion can lead us to imagine the impulse of the line. This account might sound vulnerable to the caveat Jan Baetens offered in his otherwise very positive assessment of Phillippe Marion's theory of 'graphiation', in that it privileges expressive linework that draws attention to itself as a physical trace (2001), but Podro extends his account of the way in which drawn lines direct our attention to the depicted form to be able to include the kind of considered, distilled facture of a Herge or Chris Ware: this process of the double-relation of the line to the figure includes 'also ... the controlled complexity of the drawing itself imparting to the figure the poise and concentration of the drawing' (Podro 1998: 9).

In the accounts of depiction developed by Walton, Podro and Maynard, the cognitive content of perceptual activity is a grounding assumption: 'experiences contain thoughts ... the seeing and the imagining are inseparably bound together, integrated into a single complex phenomenological whole' (Walton 1990: 295, original emphasis). Recent developments in cognitive science have provided empirical bases for such assessments of the cognitive content of perception. The proposed role of mirror neurons, for example, links perception of motion and physical motor activity on an unconscious, neural level: 'The same mirror neurons fire when you perform an action or you see someone else performing that action ... they are active not only when acting or perceiving the same action but also when imagining that you are perceiving or performing an action' (Lakoff 2008: 19). Karin Kukkonen (2013) argues for the role of mirror neurons in our understanding of motion in comics. Using the motion of figures in a page of Winsor McCay's Dreams of the Rarebit Fiend as her primary example, she argues that we understand their movements through space by running a mental simulation, and much as we do not choose to see a red-roofed mill in Hobbema's painting, but imagine its presence on seeing the marks from which it is constructed, this simulation is a cognitive activity initiated simply by viewing the sequence of panels. Equally, when following the sweeping curve of Smiley's foot, we cannot help but imagine, and imagine performing, the action which has left that mark as its trace. 
There are two distinct sets of fictional truths generated by our attention to these lines. Although the fluidity of Smith's brushstrokes contribute to an overall feeling of motility in Bone's (2004) pages in a manner highly appropriate to a story that has been described as 'one long, fluid chase scene' (Clough 2010), the movements we imagine being made in his construction of the images do not directly echo the movements we attribute to the depicted characters. Kukkonen's discussion focuses on our perception and simulation of the depicted movements of McCay's characters, and where she addresses specific aspects of the rendering of these images, her focus is on what she calls compositional lines, which 'are often rendered in bodies of characters and create an immediate bodily understanding of their (conceptual) relation to each other or to objects in the storyspace'. In Figure 1, panel 6, significant compositional lines rendered in Smiley Bone's body would include the diagonal movement of the lines that delineate his left leg, and the exaggerated size of his left foot, emphasizing the thrust of his gait and the breezy confidence he exudes throughout the book. This thrust is further emphasized by the perspectivally receding lines of the cage at the right of the panel, and by the contrast between Smiley's forward motion in this panel and his recoiling from the odour of the cheese in the preceding two.

Figure 2: Smith (2004: 1238, panel 6) (digital tracing with a fixed-width brush by the author).

If the lines that construct an image are shorn of variety in weight and texture, as in Figure 2 , the effects of these compositional features on our understanding of the characters' interaction with the storyworld remain to an extent, but with a reduced vivacity. The gestural and compositional properties of any given line cannot be entirely separated: the thick marks that delineate Smiley's body in Figure 1 operate compositionally to separate him more forcefully from the background and bring him further 'downstage' in the original panel than he appears to be in the modified version. But when the tapering at either end of the outline of Smiley's foot is removed, we are much less 
inclined to simulate the gesture of which this mark is a trace. In Walton's terms, the use we can make of this prop in Figure 2 is further attenuated - the speed with which our eyes travel along the modified line is reduced, and by extension the character to whose depiction that line contributes becomes less obviously mobile. The fictional truths we generate about the creation of a narrative drawing contribute directly to our understanding. Although we know that it is factual, not fictional, that the lines in Figure 1 do result from gestures made by Smith, I refer to the truths generated by our examination of his mark-making as fictional because we can retrieve no direct information about the experience or state of mind of the drawer. As Deanna Petherbridge reminds us, although '[w]ithin the linear economy, gestural mark-making ... is, or appears to be, a trace of performative action and embodied state', 'the supposed passion of a stroke or entire drawing may be entirely counterfeit' (2010: 103, original emphasis).

I propose, based on the preceding, that an embodied account of the understanding of comics texts may prove fruitful in the examination of the effects of different drawing styles on narrative meaning. The stated purpose of this article, however, is to examine some features of comics drawing within the framework of Walton's theory of depiction, so I turn now to a common trope of cartooning that is less obviously depictive than the examples discussed so far.

\section{Emanata}

What are we to make of emanata, the species of pictorial rune (Kennedy 1982) frequently used in comics and cartoons to represent smells, heat, dizziness, rage and a myriad of other non-visual elements? Do they function as depictions according to this framework? They do seem to fit the investigative criterion of depictions: we generate relevant fictional truths about the nature of the emanation by examining the marks from which it is constructed. A larger set of wavy lines indicates that a smell is stronger or is carried further than one made of small lines, and its rendering in jagged strokes or saturated green may indicate that the smell is unpleasant. But it is less easy to claim that 
we take our seeing of the lines rising from the 'soft stinky-cheese' in Figure 1 as an object of imagining in the same way that we do the depicted cheese itself. Walton expresses a similar doubt, but leaves the matter open to some degree: 'the cartoon probably does not depict the sounds or smells that it represents' (1990: 332, emphasis added).

In his discussion of emanata in Asterix et la Zizanie (Asterix and the Roman Agent), Forceville (2005) employs conceptual metaphor theory, which shares with Kukkonen's discussion of depicted motion a grounding in the notion of embodied cognition. Kovecses (1986) argues that many of our common idiomatic expressions for anger are structured by an Idealized Cognitive Model, or folk theory, described linguistically as 'anger is the heat of fluid in a container'. This is a complex conceptual metaphor in which anger is conceived as a substance that rises within the human body the container in this metaphor. When we speak of someone 'boiling with rage' we are drawing on this conceptual structure, and so, argues Forceville, is Uderzo when he depicts an enraged Gaul or Roman emitting steam from his head. Forceville identifies a number of drawn elements that recur throughout Asterix et la Zizanie (Asterix and the Roman Agent), which vary in how easily we can categorize them as depictions. A reddening of the cheeks is a manifestation of anger that we can observe in real life, and characters in the books exhibit varying degrees of redness according to the degree of anger to which they have been provoked. We can gain relatively rich information about the depicted world by imagining that our seeing of the patch of red ink on Obelix's cheek is seeing Obelix redden with rage. Droplets of spittle flying from the mouth can also be observed in real life, and even when the marks that depict these are abstracted to simple straight lines it is not hard to imagine them as a stylization of features of the world. Features such as smoke rising from heads and the spiralling lines Forceville designates 'twirls' would seem to be more wholly metaphorical and lacking a direct material basis. However, research aimed at strengthening the empirical basis of conceptual metaphor theory has suggested that in strongly established conceptual metaphors, the conceptual domains involved are activated simultaneously and automatically (Lakoff 2008): on 
seeing the smoke rising from a character's head, we do not have to consciously interpret the visual information, nor even, as experienced comics readers, quickly draw on a familiar visual lexicon to infer the meaning 'this character is very angry' from the image. It would seem that Walton was right not to shut the door on the possibility of emanata of various types being depictive. The viewer's actual act of looking at the smoke is the occasion for her imagining that the character is angry, and her visual examination of the smoke can reveal at least some fictional truths - most obviously, its intensity - about that anger.

\section{Conclusion}

The discussion thus far has focused on isolated passages - a line that describes a striding foot, a short sequence of panels - but in conclusion I want to suggest that this framework can also productively direct our attention to properties of complete comics texts as physical objects. Ian Hague, in a discussion of the contribution our sense of touch makes to the process of making meaning from comics, offers Chip Kidd's design for Jack Cole and Plastic Man: Forms Stretched to their Limits! (Spiegelman and Kidd 2001) as a notable example. Kidd chose to bind the book in a rubbery plastic so that it would appear to the reader as if Plastic Man had disguised himself as that book (Hague 2014: 101). In Walton's terms, we would say that it is fictionally true that when we hold the book we are holding the disguised hero. The same device is used for the covers of the collected volume of Plastic Man: On the Lam! (Baker, 2005). An image returned on the first row of results of a Google image search using that title as its terms shows a hand holding the book, with a speech bubble emanating from it that reads: 'Hey man... Can you... release me? I'm getting cramps here!'. The text that brackets this image on the comics review blog for which it was produced further emphasizes the willingness with which its creator, 'Eyz', has entered into the game of makebelieve mandated by Kidd's design choice: 'you'd expect ... a comic book called "Plastic Man", edited with a real-life plastic cover to be something quite special ... Is it a book or really Plastic Man himself?' (Eyz 2010, original emphases). Clearly, it is not only within a scholarly context that 
the principle of 'mimesis as make-believe' provides a productive and enjoyable way of approaching texts.

\section{References}

Baetens, J. (2001), 'A new theory of graphic enunciation', in R. Varnum and C. T. Gibbons (eds), The Language of Comics: Word and Image, Jackson: University Press of Mississippi, pp. 145-55.

Baker, K. (2005), Plastic Man: On the Lam!, New York: DC Comics.

Clough, R. (2010), 'New books from scholastic', http://classic.tcj.com/review/new-books-fromscholastic/. Accessed 10 April 2015.

Culler, J (2002), Structuralist Poetics: Structuralism, Linguistics and the Study of Literature, Routledge Classics ed., London and New York: Routledge.

Eyz (2010), 'CBR Plastic Man: On the lam!', http://eyzmaster.blogspot.co.uk/2010/06/cbr-plasticman-on-lam.html. Accessed 30 November 2014.

Forceville, C. (2005), 'Visual representations of the idealized cognitive model of anger in the Asterix album La Zizanie', Journal of Pragmatics, 37:1, pp. 69-88.

Gombrich, E. H. (1963), 'Meditations on a hobby horse or the roots of artistic form', in E. H. Gombrich (ed.), Meditations on a Hobby Horse and Other Essays on the Theory of Art, Oxford: Phaidon, pp. 1-11 
(2002), Art and Illusion: A Study in the Psychology of Pictorial Representation, 6th ed., London: Phaidon.

Grennan, S. (2011), 'Comic strips and the making of meaning: Emotion, intersubjectivity and narrative drawing', unpublished Ph.D. thesis, London: University of the Arts London.

Hague, I. (2014), Comics and the Senses: A Multisensory Approach to Comics and Graphic Novels, New York: Routledge.

Kennedy, J. M. (1982), 'Metaphor in pictures', Perception, 11:5, pp. 589-605.

Kovecses, Z. (1986), Metaphors of Anger, Pride, and Love: A Lexical Approach to the Structure of Concepts, Amsterdam and Philadelphia: John Benjamins.

Kukkonen, K. (2013), ‘Space, time and causality in graphic narratives: An embodied approach', in D. Stein and J.-N. Thon (eds), From Comic Strips to Graphic Novels: Contributions to the Theory and History of Graphic Narrative, Berlin and Boston: Walter de Gruyter, pp. 49-66.

Lakoff, G. (2008), 'The neural theory of metaphor', in R. W. Gibbs (ed.), The Cambridge Handbook of Metaphor and Thought, Cambridge: Cambridge University Press, pp. 17-38.

Maynard, P. (2005), Drawing Distinctions: The Varieties of Graphic Expression, Ithaca: Cornell University Press.

Petherbridge, D. (2010), The Primacy of Drawing: Histories and Theories of Practice, New Haven: Yale University Press.

Podro, M. (1998), Depiction, New Haven: Yale University Press. 
Smith, J. (2004), Bone: The Complete Cartoon Epic in One Volume, Columbus: Cartoon Books.

Spiegelman, A. and Kidd, C. (2001), Plastic Man: Forms Stretched to Theuir Limits!, San Francisco: Chronicle Books

Walton, K. (1990), Mimesis as Make-believe: On the Foundations of the Representational Arts, Cambridge: Harvard University Press.

(2008), Marvelous Images: On Values and the Arts, New York: Oxford University Press.

\section{Contributor details}

John Miers is a cartoonist and practice-based Ph.D. candidate at Central St Martins, University of the Arts London. He is a frequent contributor to, and occasional editor of, independent comics anthologies. See johnmiers.com for examples and full biography.

Contact:

Central Saint Martins College of Arts and Design

Granary Building, C107

1 Granary Square

London N1C 4AAE-mail: j.miers@csm.arts.ac.uk 